IZA DP No. 7196

China's Life Satisfaction, 1990-2010

Richard A. Easterlin

Robson Morgan

Malgorzata Switek

Fei Wang

January 2013 


\title{
China's Life Satisfaction, 1990-2010
}

\author{
Richard A. Easterlin \\ University of Southern California \\ and IZA \\ Robson Morgan \\ University of Southern California \\ Malgorzata Switek \\ University of Southern California \\ and IZA \\ Fei Wang \\ University of Southern California
}
Discussion Paper No. 7196
January 2013

\author{
IZA \\ P.O. Box 7240 \\ 53072 Bonn \\ Germany \\ Phone: +49-228-3894-0 \\ Fax: +49-228-3894-180 \\ E-mail: iza@iza.org
}

\begin{abstract}
Any opinions expressed here are those of the author(s) and not those of IZA. Research published in this series may include views on policy, but the institute itself takes no institutional policy positions. The IZA research network is committed to the IZA Guiding Principles of Research Integrity.

The Institute for the Study of Labor (IZA) in Bonn is a local and virtual international research center and a place of communication between science, politics and business. IZA is an independent nonprofit organization supported by Deutsche Post Foundation. The center is associated with the University of Bonn and offers a stimulating research environment through its international network, workshops and conferences, data service, project support, research visits and doctoral program. IZA engages in (i) original and internationally competitive research in all fields of labor economics, (ii) development of policy concepts, and (iii) dissemination of research results and concepts to the interested public.
\end{abstract}

IZA Discussion Papers often represent preliminary work and are circulated to encourage discussion. Citation of such a paper should account for its provisional character. A revised version may be available directly from the author. 


\section{ABSTRACT}

\section{China's Life Satisfaction, 1990-2010*}

Despite its unprecedented growth in output per capita in the last two decades, China has essentially followed the life satisfaction trajectory of the central and eastern European transition countries - a U-shaped swing and a nil or declining trend. There is no evidence of an increase in life satisfaction of the magnitude that might have been expected to result from the fourfold improvement in the level of per capita consumption that has occurred. As in the European countries, in China the trend and U-shaped pattern appear to be related to a pronounced rise in unemployment followed by a mild decline, and an accompanying dissolution of the social safety net along with growing income inequality. The burden of worsening life satisfaction in China has fallen chiefly on the lowest socioeconomic groups. An initially highly egalitarian distribution of life satisfaction has been replaced by an increasingly unequal one, with decreasing life satisfaction in persons in the bottom third of the income distribution and increasing life satisfaction in those in the top third.

JEL Classification: $\quad$ 131, 138, D60, 053, P36

Keywords: $\quad$ economic growth, Easterlin Paradox, happiness, life satisfaction, subjective well-being, transition countries, China

Corresponding author:

Richard A. Easterlin

Department of Economics

KAP 318B

University of Southern California

Los Angeles, CA 90089-0253

USA

E-mail: easterl@usc.edu 
The purpose of this article is chiefly to describe the trend in subjective wellbeing (SWB) during China's transition from socialism to capitalism and the differences in SWB by socio-economic status. In support of the findings on subjective well-being, we also note likely causal factors, drawing on evidence for both China and the European transition countries.

There are many who believe that well-being is increased by economic growth, and that the higher the growth rate, the greater the increase in well-being. There could hardly be a better country than China to test these expectations of increased well-being. China's transition has been marked by perhaps the highest two-decade rate of growth in gross domestic product (GDP) per capita ever seen, a remarkable 8 percent per year or more* (1). Between 1990 and 2009 per capita consumption in China (in constant dollar terms) multiplied four-fold.

The principal measure of well-being used here is self-reported feelings of satisfaction with life, one of the measures recommended in the recent Stiglitz-SenFitoussi Report (7):

All things considered, how satisfied are you with your life as a whole these days? Please use this card to help with your answer.

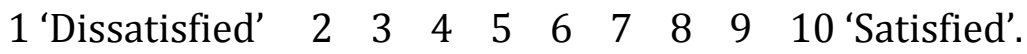

\section{Previous Studies}

Earlier work offers mixed results - from life satisfaction "falling" to "constant" to "rising." On the downtrend side there is an article by Brockmann et al

* Output statistics in this paper are from the Penn World Table (pwt.econ.upenn.edu/cic_main.html). 
(8). Kahneman and Krueger's (9) reading of the evidence tends toward "constant," but "declining" is also viewed as within the realm of possibility. Two Gallup reports offer a "flat line" conclusion $(10,11)$, as does a study by Knight and Gunatilaka (12). The basis of the Knight-Gunatilaka conclusion is an earlier collaborative article by one of the current authors (13). A recent report of the PEW Research Center sees China as experiencing rising life satisfaction along with rising incomest.

Studies of life satisfaction by Chinese scholars are growing in number, but focus on point-of-time differences (16). One of China's premier survey organizations, Horizon Research Consultancy Group, has conducted a number of valuable quality of life surveys that include questions on life satisfaction. These data are reported in the "Blue Books" issued annually by the Chinese Academy of Social Sciences (17), but there is virtually no discussion of longer term movements.

\section{Data and Methods}

The life satisfaction data used here are from six surveys conducted by five different survey organizations and span various segments of the 1990-2010 period ${ }^{\ddagger}$. Most of the surveys ask about overall life satisfaction, but several refer to roughly equivalent concepts such as "happiness" or "ladder of life". The questions vary somewhat in their specific wording and particularly in the number of response

\footnotetext{
+ Available from the 2011 Global Attitudes Project by the PEW Research Center (http://www.pewglobal.org/category/datasets/).

₹ The surveys used are: The World Values Survey (www.worldvaluessurvey.org), the Asiabarometer (www.asiabarometer.org), two surveys by Gallup $(10,11)$ available at (www.gallup.com), a survey by Horizon Research Consultancy Group (www.agmr.com/members/horizon.html), and the 2011 Global Attitudes Project by the PEW Research Center (http://www.pewglobal.org/category/datasets/).
} 
options (see Supporting Information); hence we examine the surveys individually rather than pooling the data. The survey dates are typically intermittent (only two surveys include annual data), so we focus on the longer-term movement during the two decades. Sample sizes run from around 1,000 to over 5,000 respondents, with most surveys above 2,500.

Most of the surveys tend to be disproportionately urban (such as the PEW and Asiabarometer surveys). But economic growth is also disproportionately urban during this period, with urban incomes rising markedly relative to rural $(17,18,19)$. Thus, while the life satisfaction data have an urban bias during this period, so too does economic growth, and it seems reasonable to compare the two. In all of the series but one, total, rather than urban data, are used in what follows, chiefly to maximize sample size in a country as vast as China. For the Horizon surveys we analyze the series for cities, that with the longest time span.

The analysis of trends in life satisfaction differences by socio-economic status (SES) is based on the World Values Survey (WVS). Following Inglehart et al (20), the responses on decile of income are arrayed from high to low and divided approximately into thirds, yielding upper, middle, and lower segments of the income distribution.

Historical research on a developing country like China is almost always like solving a jig-saw puzzle. Typically there are few, if any, comprehensive and tested time series available on economic and social magnitudes, but there are numerous, and sometime substantial, pieces of quantitative and qualitative data, as in the case 
of China. It is the task of the economic historian to find these pieces of data, and see if they can be put together to form a coherent picture.

\section{Results}

Longer term movement -- China's life satisfaction declines from 1990 to around 2000-2005 and then turns upward, forming, for the period as a whole, a Ushaped pattern (Fig. 1). Although precise comparison is not possible, there appears to be no increase and perhaps some overall decline in life satisfaction. A downward tilt along with the U-shape is evident in the World Values Survey (WVS), the series with the longest time span.

The other series in Figure 1 each cover shorter periods. There are fewer observations before 2000 than one might like, but in every series, including the WVS, the pre-2000 observation(s) are higher than those in the 2000-2005 trough. Similarly, observations after 2005 are higher than those in the trough, with the slight exception of the Asiabarometer series. For series with observations before and after the trough, the post-trough observations are almost always lower than the pre-trough. The one exception is the Gallup 2 series, but in this case the pre-trough date, 1999 , is virtually part of the trough.

The WVS series registers a decline from 1990 to 2007 of .53 points on a 1-10 scale. To get a better idea of the full period trend, one might ask how the likely change from 2007 to 2010 would compare with the .53 decline prior to 2007 . There are three series on which a judgment of the post-2007 change may be based. If one were to extrapolate the 2007 WVS value to 2010 based on the increases in these 
series (see Supporting Information), then the options would range from a low of .03 points (the PEW series) to .18 (using the Gallup 2 series 2011 value for the terminal observation). These post-2007 increases are much smaller than the .53 decline from 1990 to 2007, supporting the conclusion of a nil or declining trend over the full period.

Indeed, one might argue that the trend from 1990 to 2010 suggested by the present data is overstated in a positive direction, because of relatively poor coverage of the "floating population" in urban areas, those urban residents who are living in a place other than that in which they are officially registered. The life satisfaction of migrants to urban areas is typically less than that of the urban-born population (21); hence an increase in the proportion of the floating population in urban areas would tend to lower average life satisfaction for the urban population as a whole. Between 1990 and 2010 the floating population rose substantially, from perhaps 7 to 32 percent of the urban population (estimated from 22-24), exerting an increasingly negative impact on average urban life satisfaction. If the floating population is not as well covered in the life satisfaction surveys as their urban-born counterparts, then this negative impact is understated and the full period trend consequently biased upward.

It is noteworthy that there is no evidence of a substantial uptrend in life satisfaction of the magnitude one might have expected due to the four-fold increase in GDP per capita. In the happiness literature the point-of-time (cross section) relationship of happiness to GDP per capita is often used to infer the likely life satisfaction change over time as GDP per capita increases (25-27). Based on the 
international cross section regression relationship between life satisfaction and GDP per capita in the 1990 WVS data, one would have expected that from 1990 to 2010 life satisfaction would have increased by six-tenths of a point due to the four-fold increase in GDP per capita. If, alternatively, one uses the relationship of life satisfaction to GDP per capita proposed by Stevenson and Wolfers (28), then the expected increase would be about a full point. It is hard to see any indication of such sizeable full-period increases in the present data.

Recognition of the U-shape of China's changing life satisfaction leads to a consistent explanation for the mixed results of previous studies. The series analyzed by those inferring a declining trend tend to fall in the early, declining segment of the $\mathrm{U}(8,9)$. Those finding a pattern of constancy straddle the 2000-2005 trough (1013). An uptrend finding (PEW) results from a starting survey date falling in the 2000-2005 trough.

The finding of a life satisfaction trough for China around 2000-2005 is reminiscent of a similar result previously reported for Latin America, where life satisfaction in the period 1994-2006 also followed a U-shape, bottoming out around 2002 (15). It is possible that similar life satisfaction troughs occurred around this time in other developing countries, because there was a serious setback to growth of the world economy generally in the first part of the 2000-2010 decade $(29,30)$.

China's long-term movement of life satisfaction is like that of other transition countries, in that life satisfaction declines early in the transition and then recovers. China's initial decline in life satisfaction, 0.76 points from 1990 to the 2001 trough WVS observation, is of the same order of magnitude but a little less than the average 
(0.91) of the six European transition countries for which similar peak to trough calculations can be made. Such sizeable declines in life satisfaction are quite rare (4).

In the European transition countries, as for China, it is doubtful that the recovery raises life satisfaction above pre-transition values (4). In China, however, the average level of life satisfaction from 1990 to 2007 (above 6.5 according to the WVS) was higher than in most of the European transition countries during that period.

As previously indicated, in point-of-time international comparisons, life satisfaction and GDP per capita are significantly positively correlated. The 1990 WVS value for life satisfaction in China is high relative to its GDP per capita. Of the 35 countries in the 1990 WVS for which GDP per capita estimates are available, China ranks 18th in terms of life satisfaction, just below most of the developed countries. In terms of GDP per capita it ranks 33rd.

The 1990 WVS value contributes to the judgment that life satisfaction in China has not increased and may even have declined in the last two decades. But is this value credible? One reason for thinking so is that in 1990 virtually all socioeconomic groups in China - from the lowest to the highest stratum - report high and fairly similar mean levels of life satisfaction, in excess of 7.0. These high levels appear throughout the distributions by education, occupation, and income. Hence, the high overall average cannot be attributed to a disproportionate representation in the survey of high life satisfaction groups. 
In addition, China's 1990 value of 7.29 for mean life satisfaction is virtually identical to the value (7.26) in the fragmentary pre-transition data for the Soviet Union, the country whose labor and wage policies served as the model for communist China $(4,18)$. Moreover, in 1990 life satisfaction inequality in the two countries is also almost the same (Table S4).

Confidence in the 1990 WVS data is further bolstered by the fact that the internal structure of the data set is much like that observed in happiness data sets for other countries. A micro-economic happiness regression of the usual type (25, 31,32 ) yields coefficients on variables such as age, marital status, income, health, and unemployment with signs like those commonly found in other countries. These coefficients are not always significant, probably because of the low degree of variability in life satisfaction in the 1990 data for China. A 1990 microeconomic regression for Russia yields results similar to China in terms of both the signs and lack of significance of the coefficients.

Finally, as we shall see, the high 1990 level of life satisfaction in China is consistent with the quite low unemployment rate and the extensive social safety net prevailing at that time - urban workers were essentially guaranteed life-time positions and the benefit package associated therewith, including such things as subsidized food, housing, health care, pensions, and jobs for grown children (36).

The historical context -- The U-shape pattern of life satisfaction from 1990 to 2010 largely mirrors an inverted $\mathrm{U}$ in the urban unemployment rate (Figure 2). The unemployment rate rose markedly in the 1990s, peaked in the 2000-2005 period, and then declined somewhat, though remaining above its initially very low level. 
(For a valuable assessment of China's unemployment data, including the officially registered unemployed, see 34).

The growth rate of GDP moves somewhat inversely to the unemployment rate, but bottoms out earlier, from 1997 to 2001, at a still healthy average of 3.6 per cent per year (37). The inflation rate, as measured by the consumer price index (CPI), trends upwards 1990 to 1997, levels off through 2003, and resumes its increase thereafter, but at a slower rate (38). Based on the literature (39), the expectation is that low inflation increases life satisfaction, but in the period when inflation was at its lowest in China, so too was life satisfaction.

The causality suggested by the inverse swings in life satisfaction and the unemployment rate is consistent with the repeated findings in the happiness literature that unemployment reduces life satisfaction (31, 40-42). Moreover, the evidence is that life satisfaction is reduced, not only for those who become unemployed, but for employed persons as well, presumably due to the anxiety created by a worsening labor market (39).

The apparent link between life satisfaction and unemployment is supported also by the sensitivity to economic conditions of the population in China evidenced by their responses to the following question asked in the PEW surveys: "Now thinking about our economic situation, how would you describe the current economic situation in China - is it very good, somewhat good, somewhat bad, or very bad?" In 2002 when the unemployment rate was at or near its highest point, almost half (48 percent) of the respondents said, "somewhat" or "very bad." In 2007, when the unemployment rate, though still above its 1990 level, had substantially 
improved, the corresponding percentage was down to 14 percent, and in 2010, 7 percent. Life satisfaction in these years according to the responses to the PEW survey's question on "ladder of life" rose from 5.27 in 2002 to 5.82 in 2007 and 5.85 in 2010 .

One might suppose that the U-shaped pattern of life satisfaction is due, not to the movement in the unemployment rate, but to the U-shaped swing in the growth rate of GDP per capita mentioned above. A problem with this view is that it raises the question of why the growth rate of GDP per capita, which troughs 1997-2001, would affect life satisfaction with a lag of several years. Moreover, this view cannot account for the similarity between China's life satisfaction trajectory and that of the European transition countries whose output pattern is so markedly different from China's. The explanation of the U-shaped life satisfaction pattern that fits the experience of both China and Europe is the movement of labor market conditions, as indexed by the unemployment rate, not the growth of output.

The movement of China's unemployment rate is partly a reflection of the world economy. As noted, there was a significant slowdown in world economic growth at the start of the millennium, and countries substantially dependent on exports, such as China, felt the impact of declining foreign demand $(29,30)$.

More importantly, however, the movement in China's unemployment rate is a result of government policy, and symptomatic of the deterioration in the social safety net that had prevailed under socialism. China's urban labor market prior to reform has been characterized as an "iron rice bowl" and "mini welfare state" (18). As was mentioned, workers in state-owned-enterprises (SOEs), the firms that 
accounted for the bulk of urban employment, had permanent jobs and an extensive employer-provided social safety net $(18,36)$. From an economic point of view, this system was highly inefficient and lacked incentives, but it ensured that urban workers had income security, and was highly egalitarian.

In 1994, in the face of continuing inefficiency and unprofitability of SOEs, the government initiated a restructuring program that shortly evolved into what has been called "a draconian policy of labor shedding" (18). The resulting rise in unemployment, though cushioned somewhat by an urban layoff program that provided some temporary safety net benefits (xiagang), was aggravated by a rising rural to urban movement as policies restricting internal migration were gradually relaxed (36). As described in a World Bank Report: "By all measures, SOE restructuring had a profound effect on the functioning of the labor market and the welfare of millions of urban workers. Most urban centers experienced a sharp rise in unemployment and a large reduction in labor force participation as many older and discouraged workers left the workforce" (43). SOE restructuring also meant "the end of the 'iron rice bowl' of guaranteed life time employment and benefits for urban workers" (43).

Beginning around 2004, the rate at which SOEs were downsized diminished sharply. Between 1995 and 2003, reduced employment in SOEs far exceeded increased employment elsewhere in the urban sector; thereafter the situation was reversed and the unemployment rate declined somewhat $(2,35)$.

China's labor market developments are similar to those of the European transition countries. There is, first, the emergence of substantial unemployment. 
Second is a decline in the proportion of employed persons in the working age population due to a substantial drop in the labor force participation rate of women and older workers $(4,43)$. Third, in China as in Europe, the social safety net was greatly diminished with the transition to free market conditions. A recent World Bank report (44) on China's unemployment insurance system states that " $[t]$ he level of benefits remains low and provides a much lower income replacement rate than other countries." Much the same is true of the present pension system, which has been characterized as a "patch work of arrangements" whose "effective replacement rates are fairly low and projected to decline further" (3). Rural migrants to urban areas, numbering well over 100 million, typically have little or no safety net coverage (45).

Unlike Europe, average real wages in China rose markedly in the course of the transition, along with the very high rate of GDP growth. The fact that life satisfaction in China failed to increase noticeably along with income and output, and is similar in its U-shape to that of the European transition countries, is indicative of the fundamental importance of employment and the social safety net in determining the course of life satisfaction.

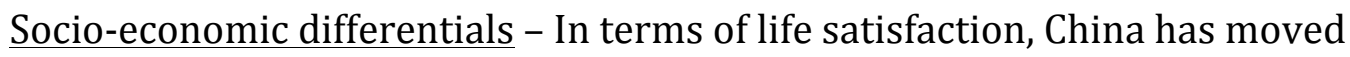
from one of the most egalitarian countries to one of the least. The beneficiaries of the transition have been the higher income and better-educated segments of the population whose life satisfaction has increased. The lower segments of the distribution have experienced a substantial decline in life satisfaction. 
In 1990, among those in the highest third of the income distribution, the proportion reporting high levels of life satisfaction (values of 7 to 10 , on a 1 to 10 scale) was 68 percent; among those in the lowest third, it was almost the same, 65 percent. By 2007, the percentage in the 7-10 range had risen slightly for the upper income groups, to 71 percent; for the lower income group it had plummeted to 42 percent (Figure 3, top panel). China's trend in life satisfaction differences by SES is typical of transition countries (4), and parallels closely the trend in Russia.

Although incomes have increased for all income groups, China's transition has been marked by a sharp increase in income inequality $(18,46-48)$. The rise in income inequality is due to the growing urban-rural disparity in income, increased income differences within both urban and rural areas, and the sharp increase of unemployment in urban areas associated with restructuring (48). Knight and Song (18) point out that, “In adopting its reform policies, ...[China's] leadership espoused output objectives above all else. Where there was a conflict between efficiency objectives and equality objectives, egalitarianism was played down." The trend toward increasing SES differences in life satisfaction and income is consistent with this observation.

One indication that the growth in the inequality of life satisfaction is closely linked to that in income inequality is the response to the WVS question: "How satisfied are you with the financial situation of your household?" The pattern of responses to this question in 1990 and 2007 by the three income groups replicate closely that for life satisfaction - a clustering in 1990 and a marked divergence by 2007 (Figure 3, left panel). As in the case of life satisfaction, the trend toward 
increasing SES is upward for the highest income group, and noticeably downward for the lowest.

The growing disparity in life satisfaction reflects also the dissolution of the social safety net that, among other things, provided universal health care. Evidence of this is the responses to the WVS question: "How would you describe your health these days? Would you say it is very good, good, fair, poor, or very poor?" In 1990, the proportion in each of the three income segments responding "very good" or "good" is clustered around 56 percent, and the difference between the top and bottom thirds is only 4 percentage points (Figure 3, right panel). By 2007, the differential had widened to 28 percentage points, with the upper third improving and the lower third worsening. It seems plausible that these disparate trends reflect the adverse impact on the lower income population of the increased cost of health care resulting from the marketization of health care services. According to an OECD report (3): "Economic restructuring undermined the health care system, which became increasingly privately financed, though remaining largely publicly-provided. While the population's health status was improving, a rising number of people were priced out of treatment or fell into poverty because of health care costs."

\section{Summary and Implication}

Despite an unprecedented rate of economic growth, China's life satisfaction in the last two decades has largely followed the trajectory of the central and eastern European transition countries - a decline followed by a recovery, with a nil or declining trend over the period as a whole. There is no evidence of a marked 
increase in life satisfaction in China of the magnitude that might have been expected due to the enormous four-fold improvement in levels of per capita consumption. In its transition China has shifted from one of the most egalitarian countries in the distribution of life satisfaction to one of the least. Life satisfaction has declined markedly among the lowest income and least educated segments of the population, while rising somewhat among the upper socio-economic stratum.

The similarity of China's experience to that of the European transition countries and particularly to its role model under communism, the Soviet Union, lends credence to the results. Moreover, the life satisfaction pattern fits with the historical context. The factors shaping China's life satisfaction appear to be essentially the same as in the European transition countries - the emergence and rise of substantial unemployment, dissolution of the social safety net, and growing income inequality. The fact that China's life satisfaction failed to increase despite its differing output experience - a rapid increase versus the collapse and recovery of output in the European countries - suggests that employment and the social safety net are of critical importance in determining life satisfaction.

The one piece of evidence that seemingly does not fit China's life satisfaction pattern is the growth of output. How is it possible, one may reasonably ask, for life satisfaction not to improve in the face of such a marked advance from very low initial living levels? In answer, it is pertinent to note the growing evidence of the importance of relative income comparisons and rising material aspirations in China that tend to negate the effect of rising income $(8,12,14,50-52)$. These findings are consistent with the view common in the happiness literature that the growth in 
aspirations induced by rising income undercuts the increase in life satisfaction due to rising income itself (53-57).

Moreover, there is more to life satisfaction than material goods; there is home life and the need for secure jobs to support it, health, friends and relatives, and the like. It is possible that the lack of a marked uptrend in overall life satisfaction in China may reflect an adverse impact on life satisfaction of changes in factors like these, as has been true of the transition experience of East Germany, for which such detailed data are available (4).

A common assertion based on point-of-time comparisons of nations, is that at low levels of GDP per capita, economic growth raises life satisfaction but beyond some point this effect diminishes $(25-27,58)$. It would be hard to find a better historical test of this than China, where the material living level has demonstrably soared in the last two decades from a very low initial level. Yet China's experience demonstrates once again what has been shown before $(4,13,15,60)$ : the cross section relationship of life satisfaction to GDP per capita is a poor and misleading predictor of actual historical experience.

In policy circles there has recently been growing attention to subjective wellbeing as a complement or alternative to GDP per capita as a measure of well-being. There could hardly be a more dramatic example than China to test the comparative significance of the two measures. What the GDP measure is registering is the spectacular improvement that has taken place, on average, in material living conditions. The measure of life satisfaction is demonstrating, in contrast, that among ordinary people, especially the less-educated and lower income segments of the 
population, life satisfaction has declined noticeably as material aspirations have soared and concerns have arisen about such critical matters as finding and holding a job, reliable and affordable health care, and provision for children and the elderly. Clearly, life satisfaction is the more comprehensive and meaningful indicator of what is happening to people's lives and their well-being.

It would be a mistake to conclude from the life satisfaction experience of China, and the transition countries more generally, that there should be a return to socialism and the gross inefficiencies of central planning. But there is an important policy lesson suggested by this experience. Jobs, and job and income security, together with a social safety net, are of critical importance to life satisfaction. In the last few years the government of China has begun serious efforts to repair the social safety net $(3,44,61)$. These efforts are an encouraging portent for the future of China's life satisfaction, and particularly for the least advantaged segments of the population.

\section{ACKNOWLEDGEMENTS}

We are grateful for help to Cheng Hsiao, John Knight, Jeffrey Nugent, Andrew J. Oswald, Anke Plagnol, and John Strauss. Our special thanks to Zhang Hui of Horizon Research Consultancy Group for assistance with Horizon's survey results. We have benefited from presentations at the Rand Corporation, University of Paris, and the University of Southern California. The University of Southern California provided financial assistance. 


\section{References}

1. Chen JG, Liu SC, Wang TS (2011) The China Economy Yearbook Volume 5 (The Chinese Academy of Social Sciences Yearbooks: Economy) (Brill, Leiden).

2. OECD (2010) OECD Economic Surveys: China, Vol. 2010/6 (OECD, Beijing).

3. OECD (2010) China in the 2010s: Rebalancing Growth and Strengthening Social Safety Nets (OECD, Beijing).

4. Easterlin RA (2010) Happiness, growth, and the life cycle (Oxford University Press, New York).

7. Stiglitz, Joseph E., Sen, Amartya, and Fitoussi, Jean-Paul 2008, Report of the Commission on the Measurement of Economic Performance and Social Progress.

Available at: www.stiglitz-sen-fitoussi.fr

8. Brockmann H, Delhey J, Welzel C, Yuan H (2009) The China Puzzle: Falling Happiness in a Rising Economy. J Happiness Stud 10:387-405.

9. Kahneman D, Krueger AB (2006) Developments in the Measurement of Subjective Well-Being. J Econ Perspect 20:3-24.

10. Burkholder R (2005) Chinese Far Wealthier Than a Decade Ago--but Are They

Happier. The Gallup Organization Available at:

http://sww.gallup.com/poll/content/longin.aspx?ci=14548.

11. Crabtree S, Wu T (2011) China's Puzzling Flat Line Gallup Management Journal Available at: http://gmj.gallup.com/content/148853/china-puzzling-flatline.aspx\#1 [Accessed February 1, 2012].

12. Knight J, Gunatilaka R (2011) Does Economic Growth Raise Happiness in China? Oxford Development Studies 39(1):1-24.

13. Easterlin RA, Sawangfa O (2010) in International Differences in Well-Being eds Diener E, Helliwell JF, Kahneman D (Oxford University Press, New York), pp 166216.

14. Appleton SM, Song L (2008) Life Satisfaction in Urban China: Components and Determinants. World Development 36(11): 2325-2340.

15. Easterlin RA, McVey LA, Switek M, Sawangfa O, Zweig JS (2010) The HappinessIncome Paradox Revisited. Proc Natl Acad Sci 107(52):22463-22468.

16. Chen Z, Davey G (2008) Happiness and subjective wellbeing in mainland China. J Happiness Stud 9:589-600.

17. Chinese Academy of Social Sciences (2011), Blue Book of China's Society: Society of China Analysis and Forecast (in Chinese) (Social Sciences Academic Press, China). 18. Knight J, Song L (2005) Towards a Labour Market in China (Oxford University Press, New York).

19. Xu CG (2011) The Fundamental Institutions of China's Reforms and Development. Journal of Economic Literature 49(4):1076-1151.

20. Inglehart RF, Basanez M, Moreno A (1998) Human Values and Beliefs: A CrossCultural Sourcebook (University of Michigan Press, Michigan).

21. Knight J, Gunatilaka R (2010) Great Expectations? The subjective well-being of rural-urban migrants. World Development 38(1):113-124. 
22. Duan CR, Yang G, Zhang F, Lu XH (2008) Nine Trends in China's Floating Population since the Reform and Opening Up (in Chinese). Population Research 32(6): 30-43.

23. National Bureau of Statistics of China (2002) Report on the 1990 Population Census of China (in Chinese) Available at http://ww.stats.gov.cn/tjgb/rkpcgb/t20020404_16771.htm

24. National Bureau of Statistics of China (2011) Report on the 2010 Population Census of China (in Chinese) Available at http://ww.stats.gov.cn/tjfx/t20110428_40272253.htm

25. Frey BS, Stutzer A (2002) Happiness and Economics: How the Economy and Institutions Affect Well-Bing (Princeton University Press, Princeton).

26. Veenhoven R (1991) Is happiness relative? Social Indicators Research 24:1-34. 27. Inglehart RF (2002) Globalization and postmodern values. The Washington Quarterly 23(1):215-228.

28. Stevenson B, Wolfers J (2008) Economic Growth and Subjective Well-Being: Reassessing the Easterlin Paradox. Brookings Papers on Economic Activity 2008 (Spring): 1-87.

29. United Nations (2002) World Economic Situation and Prospects 2002 (United Nations, New York).

30. United Nations (2003) World Economic Situation and Prospects 2003 (United Nations, New York).

31. Blanchflower DG, Oswald AJ (2004) Well-being over time in Britain and the USA. Journal of Public Economics 88:1359-1386.

32. Powdthavee N (2010) How Much Does Money Really Matter? Estimating the Causal Effects of Income on Happiness. Empirical Economics 39(1):77-92.

34. Knight J, Xue JJ (2006) How High is Urban Unemployment in China? Journal of Chinese Economic and Business Studies 4(2):91-107.

35. Gustafsson B, Ding S (2011) in Shi Li, Hiroshi Sato, and Terry Sicular, eds., Rising Inequality in China: Challenge to a Harmonious Society (Cambridge University Press, New York). Available at:

http://economics.uwo.ca/centres/cibc/wp2011/Gustafsson_Ding17.pdf

36. Cai F, Park A, Zhao YH (2008) in China's Great Economic Transition, eds. Brandt

L, Rawki TG (Cambridge University Press, New York), pp 167-214.

37. Liu, Shucheng (2011) in The China Economy Yearbook, Volume 5 eds Chen JG, Li

$\mathrm{SC}, \mathrm{Wu}$ TS (Brill, Leiden)

38. National Bureau of Statistics of China (2010) China Statistical Yearbook 2010 (in Chinese) (China Statistics Press, Beijing).

39. DiTella R, MacCulloch RJ, Oswald AJ (2001) Preferences over Inflation and Unemployment: Evidence from Surveys of Happiness. Am Econ Rev 91(1)

March;335-241.

40. Clark A, Georgellis Y, Sanfey P (2001) Scarring: The Psychological Impact of Past Unemployment. Economica 68:221-241.

41. Kassenboehmer SC, Haisken-DeNew JP (2009) You're Fired! The Causal Negative Effect of Entry Unemployment on Life Satisfaction. The Economic Journal 119:448462.

42. Winkelmann L, Winkelmann R (1998) Why Are the Unemployed So Unhappy? 
Evidence from Panel Data. Economica 65:1-15.

43. World Bank (2007) China's Moderninzing Labor Market: Trends and Emerging Challenges (World Bank, Washington DC).

44. Vodopivec M, Tong MH (2008) China: improving unemployment insurance (World Bank, Washington $D C$.).

45. Cai F, Wang MY, Wang DW (2010) The China Population and Labor Yearbook Volume 2 (The Chinese Academy of Social Sciences Yearbooks: Population and Labor) (Brill, Leiden).

46. Gustafsson BA, Li S, Sicular T (2008) Inequality and Public Policy in China (Cambridge University Press, New York).

47. Knight J, Song L (2000) The Rural-Urban Divide: Economic Disparities and Interactions in China (Oxford University Press, New York).

48. Cai HB, Chen YY, Zhou LA (2010) Income and Consumption Inequality in Urban China: 1992-2003. Economic Development and Cultural Change 58(3): 385-413.

50. Oshio T, Nozaki K, Kobayashi M (2011) Relative income and happiness in Asia: Evidence from nationwide surveys in China, Japan, and Korea. Social Indicators Research: Volume 104(3):351-367.

51. Smyth R, Nielsen I, Zhai QG (2010) Personal Well-being in Urban China Social Indicators Research 95:231-251.

52. Tao HL, Chiu SY (2009) The Effects of Relative Income and Absolute Income on Happiness. Review of Development Economics 13(1):164-174.

53. Clark, A. E., Frijters, P., Shields, M. A. (2008) Relative Income, Happiness, and Utility: An Explanation for the Easterlin Paradox and Other Puzzles. Journal of Economic Literature 46(1): 95-144.

54. Graham C (2009) Happiness Around the World (Oxford University Press, New York).

55. Easterlin RA (2001) Income and Happiness: Towards a Unified Theory. The Economic Journal 111:465-484.

56. Easterlin, RA (2003) Explaining Happiness. Proc Natl Acad Sci 100(19): 1117683.

57. Layard, R. (2005) Happiness: Lessons from a New Science (Penguin Press, New York).

58. Diener E, Sandvik E, Seidlitz L, Diener M (1993) The relationship between income and subjective well-being: Relative or Absolute? Social Indicators Research 28:195-223.

59. Deaton, A (2008) Income, Health, and Well-Being around the World: Evidence from the Gallup World Poll. J Econ Perspect 22(2): 53-72.

60. Easterlin RA (2005) Diminishing Marginal Utility of Income: Caveat Emptor. Social Indicators Research 70(3):243-255.

61. Barnett S, Chalk N (2010) Building a Social Safety Net. Finance and Development: September 2010: 1-2. 


\section{Figures}

Fig. 1. Mean Life Satisfaction, Six Series, 1990-2010 (Table S1). The integer response options of the series are, respectively: WVS, 1-10; Gallup 1, 1-4; AB, 1-5; Gallup 2, 0-10 except 1999, 2004, 1-10; Horizon, 1-5, except 1997-1999, 2001, 1-4; PEW, 0-10. Series with response options of 1-4 or 1-5 are plotted to twice the scale of series with 1-10 and 0-10 response options. For survey questions, see Supporting Information.

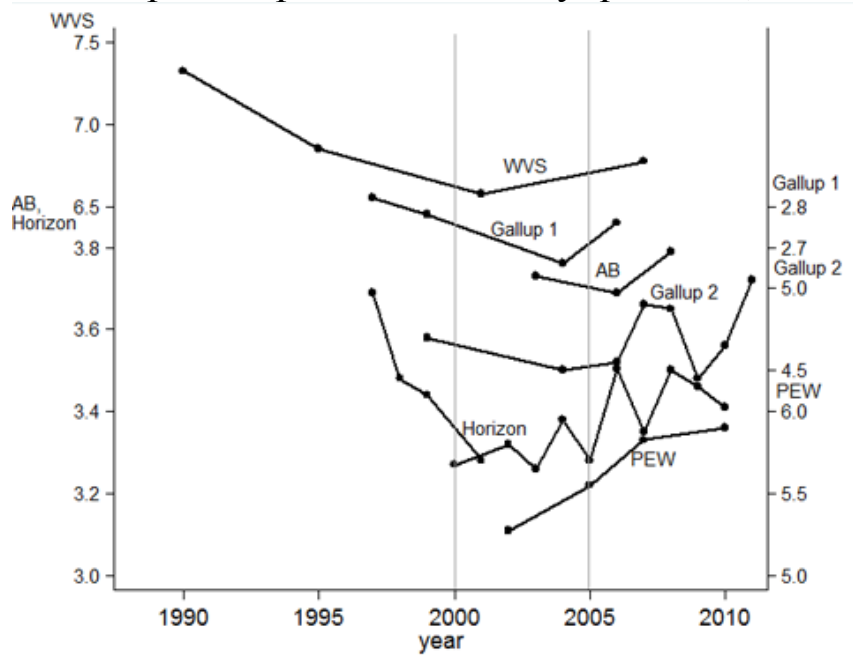

Fig. 2. Urban Unemployment Rate, 3 Series, 1988-2008 (percent of labor force) (Table S2). Source: ref. 2, 34, 35.

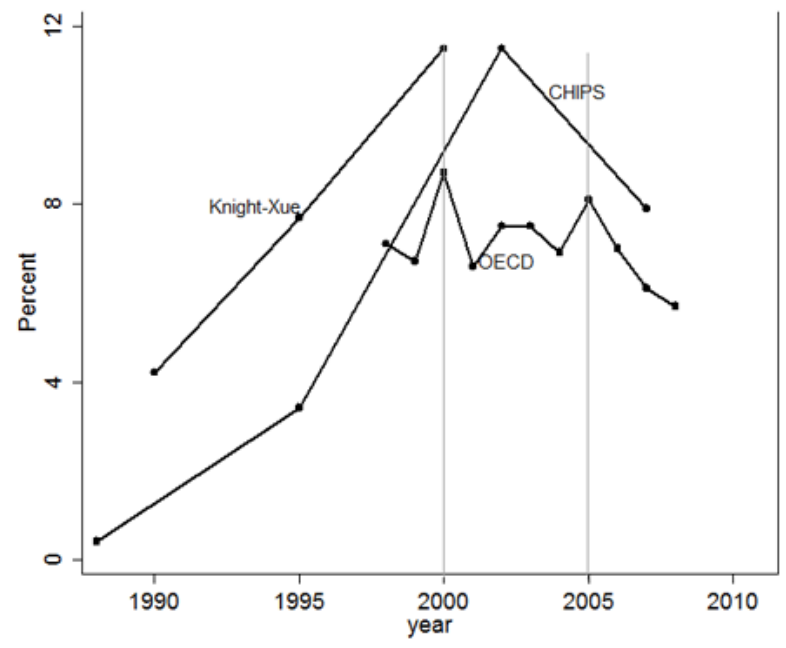


Fig. 3. Life Satisfaction, Financial Satisfaction, and Self-Reported Health of Specified Income Group, 1990 and 2007 (Table S3). Source: WVS.
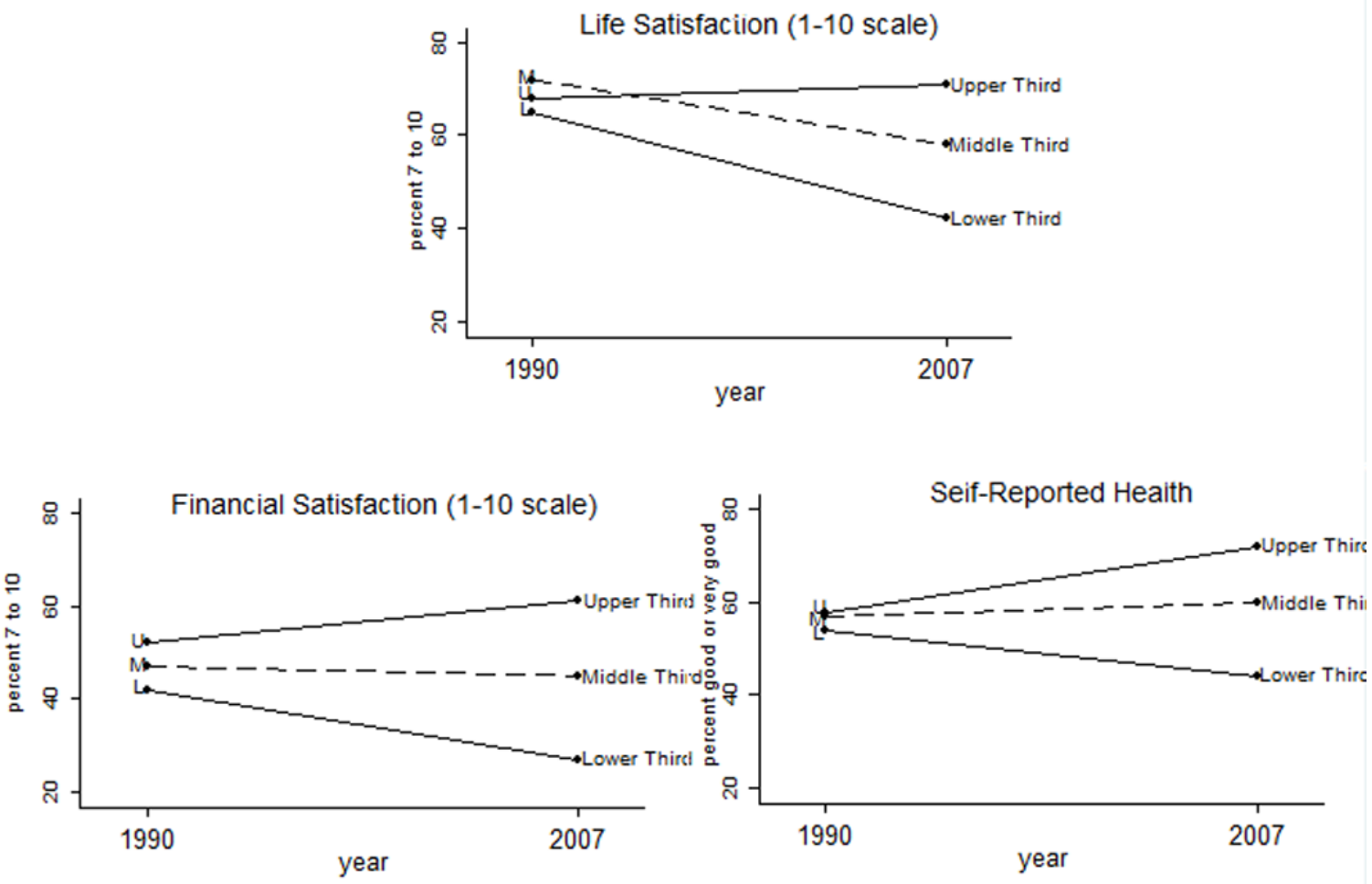


\section{Materials and Methods}

Listed below are the questions on subjective well-being, response options,

and sample sizes of the various surveys.

World Values Survey (Sample size: ca. 1,000-2,000)

Life satisfaction: All things considered, how satisfied are you with your life as a whole these days? Please use this card to help with your answer.

1 'Dissatisfied' 2345678910 'Satisfied'

Financial satisfaction: How satisfied are you with the financial situation of your household? If ' 1 ' means you are completely dissatisfied on this scale and ' 10 ' means you are completely satisfied, where would you put your satisfaction with your household's financial situation?

\section{1 'Dissatisfied' 2345678910 'Satisfied'}

Self-reported health: All in all, how would you describe your state of health these days? Would you say it is very good, good, fair, poor, or very poor?

Gallup 1 (Sample size: ca. 3,500)

Life satisfaction: Overall, how satisfied or dissatisfied are you with the way things are going in your life today? Would you say you are $4=$ Very satisfied; $3=$ Somewhat satisfied; 2 = Somewhat dissatisfied; 1 = Very dissatisfied?

Asiabarometer (Sample size: ca. 1,000-2,000)

All things considered, would you say that you are happy these days?

1) Very happy

2) Quite happy

3) Neither happy nor unhappy

4) Not too happy

5) Very unhappy

Recoded with 5=Very happy. In 2003, "pretty happy" replaced "quite happy."

Gallup 2 (Sample size: ca. 4,000)

Ladder of life: Please imagine a ladder with steps numbered from 0 at the bottom to 10 at the top. Suppose we say that the top of the ladder represents the best possible life for you, and the bottom of the ladder represents the worst possible life for you. On which step of the ladder would you say you personally stand at this time?

\section{Horizon}

(1997-1999, 2001) (Sample size: ca. 5,000)

(in Chinese) In general, are you satisfied with your current life? Very satisfied, fairly satisfied, fairly dissatisfied, or very dissatisfied? (single answer) Coded 5,4,2,1. 
(2000, 2002-2010) (Sample size: ca. 2,500-5,500)

(in Chinese) In general, are you satisfied with your current life? Very satisfied, fairly satisfied, average, fairly dissatisfied, or very dissatisfied? (single answer)

Coded 5,4,3,2,1.

PEW (Sample size: ca. 3,000)

Here is a ladder representing the "ladder of life". Let's suppose the top of the ladder represents the best possible life for you; and the bottom, the worst possible life for you. On which step of the ladder do you feel you personally stand at the present time?

Response options: 0-10. 
Table S1. Mean Subjective Well-Being, Six Series, Total Population, China, 19902011 $^{\mathrm{a}}$

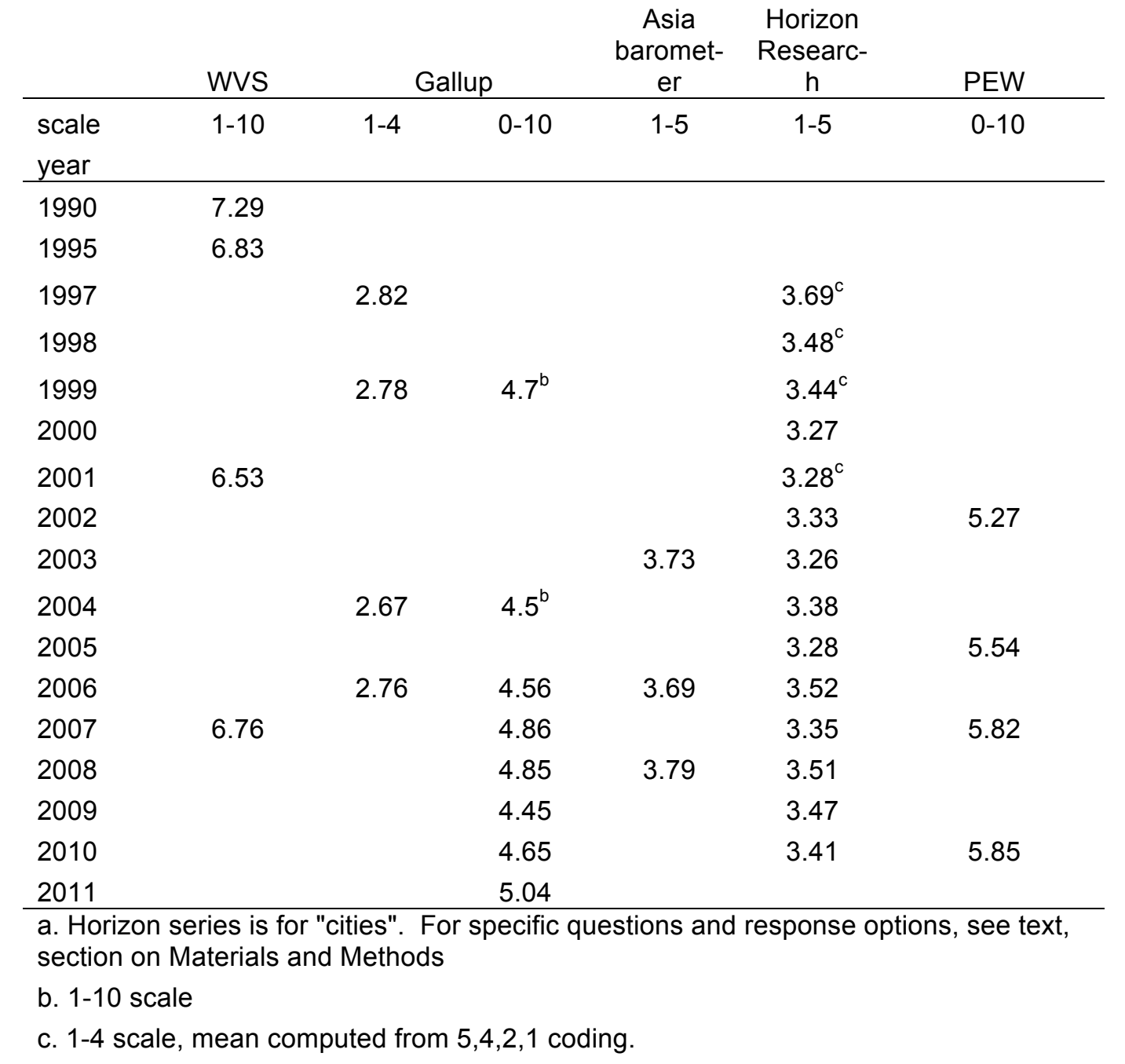


Table S2. Urban Unemployment Rate, 3 Series, 1988-2008 (percent of labor force)

\begin{tabular}{cccc} 
Kear & $\begin{array}{c}\text { Knight } \\
\text { and } \\
\text { Xue }\end{array}$ & CHIPS & OECD \\
\hline 1982 & 4.2 & & \\
1988 & & 0.4 & \\
1990 & 4.2 & & \\
1995 & 7.7 & 3.4 & \\
1998 & & & 7.1 \\
1999 & & & 6.7 \\
2000 & 11.5 & & 8.7 \\
2001 & & & 6.6 \\
2002 & & 11.5 & 7.5 \\
2003 & & & 7.5 \\
2004 & & & 6.9 \\
2005 & & & 8.1 \\
2006 & & & 7.0 \\
2007 & & 7.9 & 6.1 \\
2008 & & & 5.6 \\
\hline
\end{tabular}


Table S3. Life Satisfaction, Financial Satisfaction, and Self-Reported Health of Specified Income Group, 1990 and 2007

\begin{tabular}{lcccccc} 
& Life Satisfaction & Financial Satisfaction & Self-Reported Health \\
\hline & (percent responding & 7-10 & on a 1-10 & scale) & (percent good or very good) \\
\hline Income & \multicolumn{7}{c}{} & & & & & \\
group & 1990 & 2007 & 1990 & 2007 & 1990 & 2007 \\
Upper third & 68 & 71 & 52 & 61 & 58 & 72 \\
Middle third & 72 & 58 & 47 & 45 & 57 & 60 \\
Lower third & 65 & 42 & 42 & 27 & 54 & 44 \\
All & 68 & 59 & 46 & 47 & 56 & 61 \\
\hline
\end{tabular}


Table S4. Difference in Life Satisfaction between Upper and Lower Income Groups, WVS, Wave 2 (ca. 1990) and Wave 5 (ca. 2006), China, Russia and Mean of All Countries Surveyed (percentage points)

\begin{tabular}{lcc}
\multicolumn{1}{c}{ Country } & ca.1990 & ca.2006 \\
\hline China & 3 & 29 \\
Russia & 5 & 25 \\
All & 14 & 24 \\
\hline
\end{tabular}

